\title{
Influence of superheating on casting of $\gamma$-TiAl
}

\author{
Joaquim Barbosa $^{\mathrm{a}, *}$, C. Silva Ribeiro ${ }^{\mathrm{b}, 1}$, A. Caetano Monteiro ${ }^{\text {a }}$ \\ ${ }^{a}$ Universidade do Minho, Departamento de Engenharia Mecânica, Campus de Azurem, 4800-058 Guimarães, Portugal \\ ${ }^{\mathrm{b}}$ FEUP, Departamento de Engenharia Metalúrgica e Materiais, 4100 Porto, Portugal
}

Received 24 October 2006; received in revised form 20 November 2006; accepted 21 November 2006

Available online 16 January 2007

\begin{abstract}
In this work, a Ti-48Al alloy was induction melted and allowed to cool and solidify in a $\mathrm{ZrO}_{2}$ based crucible with an inner layer of $\mathrm{Y}_{2} \mathrm{O}_{3}$, and the effect of superheating parameters (time and temperature) on the metal-crucible interface, alloy chemical composition, microstructure and microhardness is evaluated. Microhardness variation and segregation profiles of residual elements, namely yttrium and oxygen, from the surface to the inside of samples are presented and compared, in order to establish a relationship between the processing parameters, alloy contamination and the "alpha-case" extent. The alloy microstructure at the metal-crucible interface is characterized for each superheating time and temperature. The $\mathrm{Y}_{2} \mathrm{O}_{3}$ crucible layer was found to suffer some erosion and be slightly dissolved by the molten alloy and the extent of that dissolution, and consequent metal contamination with yttrium and oxygen, depend on both superheating temperature and holding time. A relationship was found between oxygen concentration profiles and microhardness profiles of the $\alpha_{2}+\gamma$ microconstituent, from the surface to the inside of samples, which depends on the superheating temperature, but is not affected by the holding time.
\end{abstract}

(c) 2006 Elsevier Ltd. All rights reserved.

Keywords: A. Titanium aluminides, based on TiAl; B. Surface properties; C. Casting; C. Melting; D. Microstructure

\section{Introduction}

The main industrial applications of titanium aluminides are in areas where the combination of high tensile properties, creep strength and corrosion resistance, associated with superior strength-to-weight ratio is important, and cost is not a crucial factor, like aeronautical, aerospace and military equipments. In the short term, the production of titanium parts is expected to increase significantly as a result of new emerging markets, like the automotive industry, sports equipment and biomedical and biomechanical applications, as well as the development of new and cheaper processing techniques than those used so far. Important steps to decrease significantly the present high cost of titanium parts might be the use of the investment casting process using traditional ceramic crucible

\footnotetext{
* Corresponding author. Tel.: +351 253510220; fax: +351 253516007. E-mail address: kim@dem.uminho.pt (J. Barbosa).

${ }^{1}$ Tel.: +351 222041786; fax: +351 222041792.
}

melting and melting stocks made of commercially pure titanium and other elements of the alloy [1-3]. The use of suitable crucible and moulding materials would avoid both the use of specially designed high cost melting furnaces and the production of mother alloys with the desired composition by multiple remelts, decreasing the production costs $[1,3,4]$.

However, the production of titanium castings is not an easy task, mainly due to the high reactivity of the alloys with traditional refractory materials used in the production of moulds and melting crucibles. Titanium and titanium alloys, namely titanium aluminides, present very low fluidity at pouring temperatures, requiring a significant amount of superheating in order to avoid misrun and cold laps in the cast parts [5,6]. On the other hand, titanium castings are usually complex shaped parts, with thin walls in order to be as light as possible, which require a high metal pouring temperature and/or a high mould preheat temperature. Research so far reveals that the use of low superheating temperatures and high mould preheat temperatures, associated with pressure assisted pouring, like centrifugal pouring, is usually the best solution to avoid 
simultaneously casting defects like misrun and cold laps, metal chemical contamination and solidification defects like shrinkage [1,2,5]. Nevertheless, turbulence associated with the pouring operation may lead to gas entrapment in the solidified cast part, in the shape of bubbles, or even to the formation of oxide films that can be found both in the interdendritic shrinkage cavities and in the inner surface of the entrained bubbles [6].

When melting is performed in a ceramic crucible, the control of the superheating parameters is crucial in order to decrease the probability of a metal-crucible interaction, and consequent contamination of the cast alloy with elements coming from the crucible material, like oxygen for example $[1,3,4]$. When this happens, embrittlement of the cast alloy $[2,3,7]$ and oxide formation can be expected [6]. On the other hand, using melting stocks based on the commercially pure elements of the alloy requires very accurate control of superheating temperature and holding time at that temperature in order to assure the chemical homogenization of the cast alloy [1].

Until now, no refractory material was found to be absolutely inert against titanium alloys and some interaction between the alloy and the crucible materials always occurs during melting, leading to metal contamination. During the last years, the authors developed extensive research in this field, and a production technique of multilayer crucibles and ceramic moulds to process titanium aluminides was developed and protected by patents $[8,9]$.

\section{Experimental}

A Ti-48Al alloy was selected for melting and was prepared from commercially pure titanium and aluminium, whose compositions are presented in Table 1. Melting charges weighing $1.3 \times 10^{-1} \mathrm{~kg}$ were melted in a 0.31 ceramic crucible induction melting furnace equipped with a $30 \%$ porosity $\mathrm{ZrO}_{2}$ based crucible with a $200 \mu \mathrm{m}$ thick $\mathrm{Y}_{2} \mathrm{O}_{3}$ face-coat, produced according to a technique described elsewhere $[3,4]$. The melting stock was positioned inside the crucible in a way that the titanium was located above the aluminium fragments in order to avoid direct contact between the Ti fragments and the crucible wall during heating. Melting was performed inside a sealed chamber, where a controlled atmosphere of commercially pure dry argon (medical grade $-\mathrm{O}_{2}<10 \mathrm{ppm} ; \mathrm{N}_{2}<5 \mathrm{ppm}$; $\mathrm{H}_{2} \mathrm{O}<1 \mathrm{ppm}$ ) was maintained at $10^{-1}$ bar. Before the heating cycle, the chamber was evacuated down to $10^{-3}$ bar and backfilled with argon five times, in order to reduce the oxygen content to a minimum level. The superheating temperatures $(T)$ were 1550 and $1600{ }^{\circ} \mathrm{C}$, and the holding times $\left(t_{\mathrm{h}}\right)$ were 60 , 90 and $120 \mathrm{~s}$ for each temperature. Temperature was measured and controlled with a type $\mathrm{B}(\mathrm{Pt}-\mathrm{PtRd})$ thermocouple with a $\mathrm{Mo}-\mathrm{Al}_{2} \mathrm{O}_{3}$ protection sheath. The heating operation was always performed at constant power and the alloy that was forming remained on a mushy state due to the dissolution of titanium in aluminium, which gradually increased the melting temperature of the alloy. When the temperature reached around $1500{ }^{\circ} \mathrm{C}$ the first liquid metal became visible, after 22 min since the start of the heating cycle. Afterwards, the thermocouple was immersed in the liquid metal to control the superheating, and power was increased in order to reach the superheating temperature as fast as possible. Heating from $1500{ }^{\circ} \mathrm{C}$ up to the desired superheating temperature took less than a minute, in order to decrease the metal-crucible contact time. For each time/temperature pair, the molten alloy was allowed to solidify and cool to room temperature inside the crucible, in order to simulate the worst practical situation concerning the occurrence of a metal-crucible interaction.

Samples for characterization were collected from the middle of the cast cylinders by sectioning them at $50 \%$ of their height. Phase identification and chemical composition were performed by quantitative EDS analysis with standards of pure $\mathrm{Ti}, \mathrm{Al}, \mathrm{Zr}$ and $\mathrm{Y}$ using a JEOL JSM 35C scanning electron microscope. A $10 \mathrm{keV}$ potential and a $100 \mathrm{~s}$ acquisition time were used. The measurement window was carefully located over the microconstituents, avoiding small inclusions of yttria dispersed on the matrix. Overall oxygen content was measured by the IGF technique (Inert Gas Fusion), and SIMS (Secondary Ion Mass Spectrometry) was used to determine the diffusion profile of oxygen from the surface to the inside of the samples. X-ray diffraction was used to identify compounds present on the metal-mould interface. Microhardness was evaluated on a Shimadzu hardness tester using a $50 \mathrm{~g}$ load for $15 \mathrm{~s}$.

The extent of the "alpha-case" was evaluated by measuring the distance from the sample surface to the point after which the microhardness assumed values similar to the average value in the bulk.

\section{Results}

\subsection{Microstructure}

For every cast sample, the as-cast microstructure contained two microconstituents: a lamellar one with a strong dendritic pattern, with two phases $\left(\alpha_{2}+\gamma\right)$, and a $\gamma$ interdendritic phase

Table 1

Chemical composition of commercially pure $\mathrm{Ti}$ and $\mathrm{Al}$ used to produce the $\mathrm{Ti}-48 \mathrm{Al}$

\begin{tabular}{|c|c|c|c|c|c|c|c|c|c|}
\hline \multirow[t]{2}{*}{ Element } & \multicolumn{9}{|c|}{ Chemical composition (wt\%) } \\
\hline & $\mathrm{O}$ & $\mathrm{H}$ & $\mathrm{N}$ & $\mathrm{C}$ & $\mathrm{Fe}$ & $\mathrm{Ti}$ & $\mathrm{Si}$ & $\mathrm{Cu}$ & $\mathrm{Al}$ \\
\hline Ti CP & 0.25 & 0.012 & 0.03 & 0.08 & 0.2 & $>99.5$ & - & - & - \\
\hline $\mathrm{Al} \mathrm{CP}$ & $0.06 \max$ & - & - & - & 0.1 & - & 0.05 & 0.01 & $>99.8$ \\
\hline
\end{tabular}




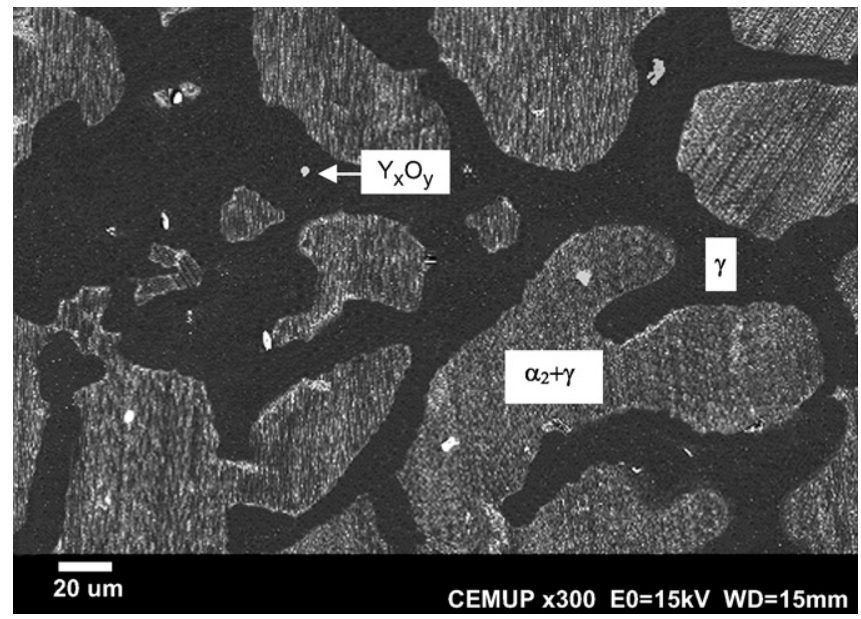

Fig. 1. Microstructure of a cast $\mathrm{Ti}-48 \mathrm{Al}$ sample, revealing the presence of small particles of yttrium oxide.

(Fig. 1). The volume fraction of the lamellar constituent was higher in every sample. The volume fraction of the interdendritic $\gamma$ phase was lower in the outside part of the samples (metal-crucible interface) and increased towards the inside, following the decrease in the cooling rate. This suggests a strong initial development of the dendritic constituent, which segregates $\mathrm{Al}$ to the melt. This microstructure is the typical TiAl bi-phase structure $\left(\alpha_{2}+\gamma\right)$ in which the amount of aluminium is slightly below $49 \%$, and the amount of $\gamma$ constituent increases with increasing $\mathrm{Al}$ content $[2,5,10]$.

Every sample revealed the presence of dispersed small nonmetallic inclusions that the EDS and XRD spectra suggest to be $\mathrm{Y}_{2} \mathrm{O}_{3}$ particles (Fig. 2).

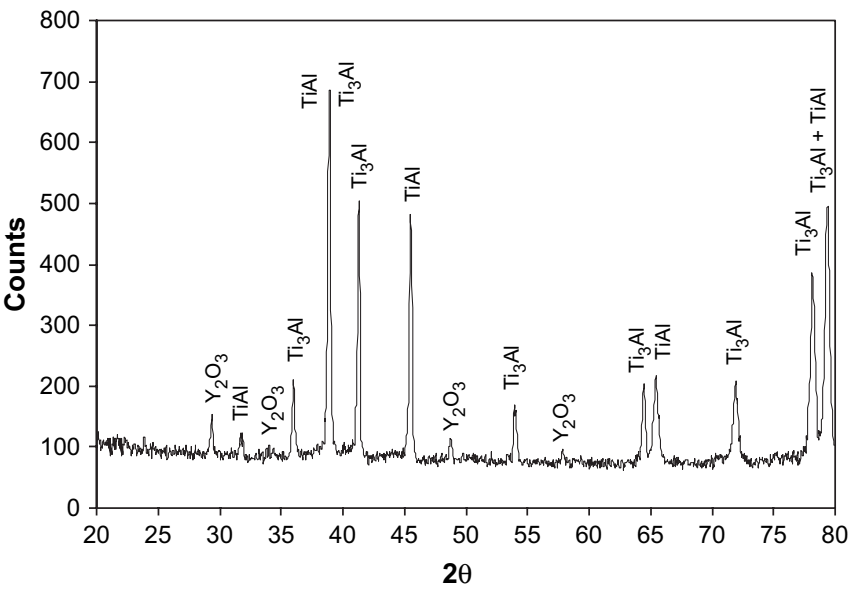

Fig. 2. X-ray diffraction spectrum of a cast Ti-48Al sample, revealing the coexistence of $\mathrm{TiAl}, \mathrm{Ti}_{3} \mathrm{Al}$ and $\mathrm{Y}_{2} \mathrm{O}_{3}$ particles.

\subsection{Chemical composition}

Tables 2 and 3 present the chemical composition of every cast sample at different distances from the sample surface, for each temperature/holding time pair determined using the technique described in Section 2.

In every sample the lamellar dendritic constituent was richer in titanium (50.2-56.2 at\%) and the monophase interdendritic constituent had a higher aluminium content (50.954.8 at\%), which agrees with the available Refs. [3,10,11]. No $\mathrm{Zr}$ was found in the cast samples, but every sample showed a slight contamination with $\mathrm{Y}$ (average values between 0.10 and 0.16 at $\%$ ), that dissolved in both microconstituents,

Table 2

Chemical composition of cast Ti-48Al samples at different depths from surface, for different holding times at $1550{ }^{\circ} \mathrm{C}$

\begin{tabular}{|c|c|c|c|c|c|c|c|c|c|c|}
\hline \multirow[t]{3}{*}{ Holding time (s) } & \multicolumn{10}{|c|}{ Chemical composition (at\%) } \\
\hline & & & \multicolumn{8}{|c|}{ Depth from surface $(\mu \mathrm{m})$} \\
\hline & & & 25 & 50 & 75 & 100 & 150 & 200 & 300 & Average \\
\hline & & $\mathrm{Al}$ & 47.5 & 45.4 & 46.9 & 48.6 & 48.0 & 46.2 & 45.6 & \\
\hline & & $\mathrm{Y}$ & 0.15 & 0.1 & $<0.10$ & 0.10 & 0.10 & 0.13 & 0.12 & \\
\hline & $\gamma$ & $\mathrm{Ti}$ & n.a. & 48.9 & 47.2 & 48.3 & 49.1 & 46.5 & 47.2 & \\
\hline \multirow[t]{4}{*}{90} & $\alpha_{2}+\gamma$ & $\mathrm{Ti}$ & 52.6 & 51.1 & 52.65 & 54.4 & 50.7 & 51.2 & 50.2 & $\mathrm{Ti}-51.71, \mathrm{Al}-48.17, \mathrm{Y}-0.11$ \\
\hline & & $\mathrm{Al}$ & 47.2 & 48.8 & 47.24 & 45.5 & 49.3 & 48.7 & 48.7 & \\
\hline & & $\mathrm{Y}$ & 0.18 & 0.12 & 0.11 & 0.12 & $<0.1$ & 0.14 & 0.11 & \\
\hline & $\gamma$ & $\mathrm{Ti}$ & n.a. & 47.9 & 47.3 & 48.3 & 48.9 & 48.8 & 46.5 & \\
\hline & & $\mathrm{Y}$ & 0.20 & 0.18 & 0.13 & 0.10 & 0.13 & 0.14 & 0.14 & \\
\hline & $\gamma$ & $\mathrm{Ti}$ & n.a. & 46.2 & 46.9 & 45.5 & 46.2 & 46.7 & 45.9 & \\
\hline & & $\mathrm{Al}$ & n.a. & 53.6 & 53.0 & 54.4 & 53.7 & 53.3 & 54.1 & \\
\hline & & $\mathrm{Y}$ & n.a. & 0.13 & $<0.1$ & 0.11 & 0.10 & $<0.1$ & $<0.1$ & \\
\hline
\end{tabular}


Table 3

Chemical composition of cast Ti-48Al samples at different depths from surface, for different holding times at $1600{ }^{\circ} \mathrm{C}$

\begin{tabular}{|c|c|c|c|c|c|c|c|c|c|c|}
\hline \multirow[t]{3}{*}{ Holding time (s) } & \multicolumn{10}{|c|}{ Chemical composition (at $\%$ ) } \\
\hline & & & \multicolumn{8}{|c|}{ Depth from surface $(\mu \mathrm{m})$} \\
\hline & & & 25 & 50 & 75 & 100 & 150 & 200 & 300 & Average \\
\hline \multirow[t]{6}{*}{60} & \multirow{3}{*}{$\alpha_{2}+\gamma$} & $\mathrm{Ti}$ & 54.6 & 54.1 & 55.5 & 53.6 & 53.1 & 54.8 & 54.0 & \multirow[t]{6}{*}{$\mathrm{Ti}-52.26, \mathrm{Al}-47.67, \mathrm{Y}<0.10$} \\
\hline & & $\mathrm{Al}$ & 45.2 & 45.8 & 44.5 & 46.5 & 46.8 & 45.1 & 45.9 & \\
\hline & & $\mathrm{Y}$ & 0.17 & 0.13 & $<0.10$ & $<0.10$ & 0.11 & 0.11 & $<0.10$ & \\
\hline & \multirow[t]{3}{*}{$\gamma$} & $\mathrm{Ti}$ & n.a. & 46.5 & 47.1 & 47.3 & 45.8 & 46.9 & 48.0 & \\
\hline & & $\mathrm{Al}$ & n.a. & 53.4 & 52.8 & 52.6 & 54.1 & 53.1 & 51.8 & \\
\hline & & $\mathrm{Y}$ & n.a. & 0.14 & 0.10 & $<0.10$ & $<0.10$ & $<0.10$ & 0.11 & \\
\hline \multirow[t]{6}{*}{90} & \multirow[t]{3}{*}{$\alpha_{2}+\gamma$} & $\mathrm{Ti}$ & 53.9 & 53.1 & 53.4 & 54.1 & 52.7 & 52.9 & 54.6 & \multirow[t]{6}{*}{$\mathrm{Ti}-51.82, \mathrm{Al}-48.06, \mathrm{Y}-0.12$} \\
\hline & & $\mathrm{Al}$ & 45.8 & 46.7 & 46.74 & 45.8 & 47.2 & 46.9 & 45.3 & \\
\hline & & $\mathrm{Y}$ & 0.22 & 0.20 & 0.11 & 0.10 & $<0.1$ & $<0.1$ & 0.11 & \\
\hline & \multirow[t]{3}{*}{$\gamma$} & $\mathrm{Ti}$ & n.a. & 47.3 & 46.9 & 46.3 & 47.0 & 47.9 & 485 & \\
\hline & & $\mathrm{Al}$ & n.a. & 52.5 & 52.9 & 53.7 & 52.9 & 52.1 & 51.4 & \\
\hline & & $\mathrm{Y}$ & n.a. & 0.16 & 0.14 & $<0.1$ & 0.1 & $<0.1$ & 0.10 & \\
\hline \multirow[t]{6}{*}{120} & \multirow[t]{3}{*}{$\alpha_{2}+\gamma$} & $\mathrm{Ti}$ & 53.0 & 52.8 & 53.8 & 53.1 & 53.2 & 53.3 & 53.0 & \multirow[t]{6}{*}{$\mathrm{Ti}-52.22, \mathrm{Al}-47.62, \mathrm{Y}-0.16$} \\
\hline & & $\mathrm{Al}$ & 46.7 & 47.0 & 46.1 & 46.7 & 46.6 & 46.5 & 47.9 & \\
\hline & & $\mathrm{Y}$ & 0.25 & 0.22 & 0.13 & 0.15 & 0.16 & 0.14 & 0.10 & \\
\hline & \multirow[t]{3}{*}{$\gamma$} & $\mathrm{Ti}$ & n.a. & 46.4 & 46.9 & 45.1 & 47.5 & 46.7 & 46.8 & \\
\hline & & $\mathrm{Al}$ & n.a. & 53.4 & 53.0 & 54.8 & 52.4 & 53.2 & 53.1 & \\
\hline & & $\mathrm{Y}$ & n.a. & 0.17 & 0.13 & 0.13 & 0.170 & 0.12 & $<0.1$ & \\
\hline
\end{tabular}

although a little more in the lamellar one (Tables 2 and 3). In every sample, the $\mathrm{Y}$ concentration was higher at the surface $\left(0.15-0.25\right.$ at $\%$ in $\alpha_{2}+\gamma$, at a distance of $25 \mu \mathrm{m}$ from the surface and $0.10-0.17$ at $\%$ in the $\gamma$ phase, at a distance of $50 \mu \mathrm{m}$ from the surface), and it decreased towards the inside of the samples until reaching the average values presented in Tables 2 and 3 . The distance from the surface where the $\mathrm{Y}$ concentration becomes constant ( $\mathrm{Y}$ diffusion depth) seems to be a function of the superheating temperature (around $50 \mu \mathrm{m}$ for $T=1550{ }^{\circ} \mathrm{C}$ and $50-75 \mu \mathrm{m}$ for $T=1600^{\circ} \mathrm{C}$ ) (Tables 2 and 3 ), which affected the crucible temperature, thus the cooling rate. The diffusion depth of $\mathrm{Y}$ was not affected by the holding time, as this parameter has no influence on the cooling rate.
The average $\mathrm{Y}$ concentration of the cast samples strongly depended on the superheating parameters and changed directly with them. In samples where the superheating temperature was $1600{ }^{\circ} \mathrm{C}$, the average $\mathrm{Y}$ content varied from 0.16 at $\%$ for $120 \mathrm{~s}$ holding time to a value less than 0.10 at $\%$ for $60 \mathrm{~s}$ holding time. Those values slightly decreased in samples where the superheating temperature was $1550{ }^{\circ} \mathrm{C}$, but kept changing directly with the holding time (from 0.14 at\% for $120 \mathrm{~s}$ holding time to less than 0.10 at\% when holding time was $60 \mathrm{~s}$ ) (Fig. 3a and Tables 2 and 3).

Besides Y, the cast alloy was found to be contaminated with oxygen, whose overall content was found to depend on both the superheating temperature and holding time $-0.21-0.26 \mathrm{wt} \%$ a)

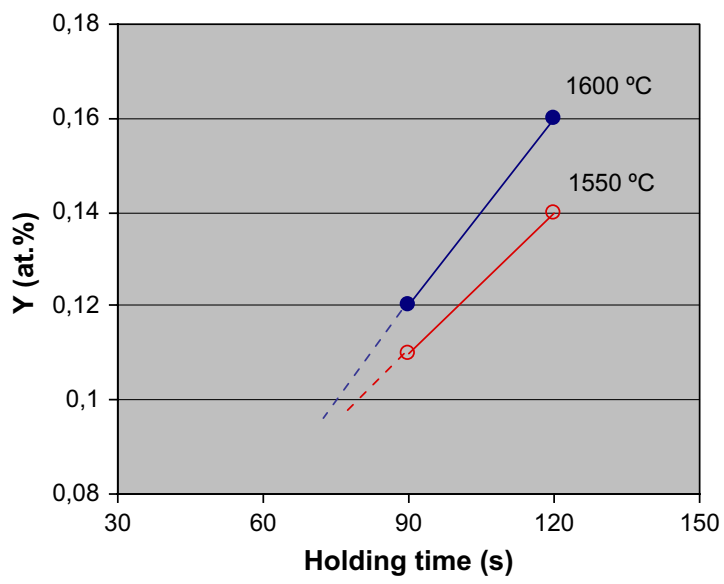

b)

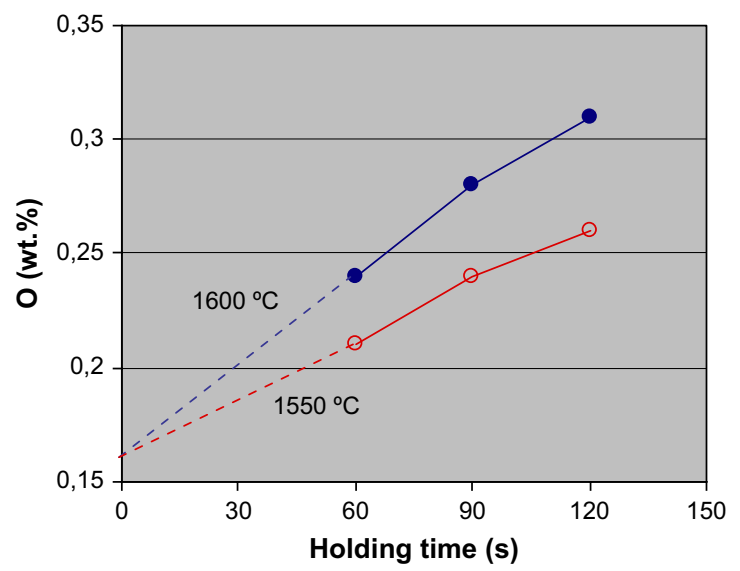

Fig. 3. Average concentration of (a) $\mathrm{Y}$ and (b) $\mathrm{O}$ in cast $\mathrm{Ti}-48 \mathrm{Al}$ samples for different holding times at 1550 and $1600{ }^{\circ} \mathrm{C}$. 


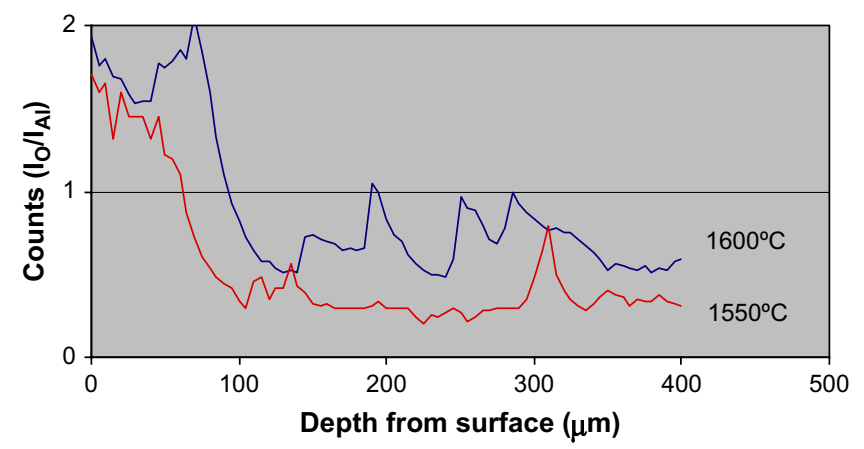

Fig. 4. Oxygen concentration profiles from the samples' surface to the inside, after $120 \mathrm{~s}$ holding time at 1550 and $1600^{\circ} \mathrm{C}$. Diffusion depth of oxygen seems to be a little more than $100 \mu \mathrm{m}$ for $T=1600^{\circ} \mathrm{C}$ and a little less than $100 \mu \mathrm{m}$ for $T=1550^{\circ} \mathrm{C}$.

for $T=1550{ }^{\circ} \mathrm{C}$ and $0.24-0.31 \mathrm{wt} \%$ for $T=1600^{\circ} \mathrm{C}$ (Fig. 3b), which agrees with other references where ceramic crucibles were used to cast Ti based alloys [1,3]. Oxygen concentration profiles from the samples surface to the inside were determined for each superheating temperature, for 120 s holding time. Fig. 4 shows those profiles and suggests that both overall and surface oxygen concentrations as well as the oxygen diffusion depth were higher for $T=1600{ }^{\circ} \mathrm{C}$, following the tendency that was found for yttrium. The diffusion depth of oxygen in the alloy (around $100 \mu \mathrm{m}$ - see Fig. 4) was higher than the yttrium diffusion depth $(50-75 \mu \mathrm{m})$, for both superheating temperatures. Peaks visible in the oxygen concentration curves obtained by SIMS (Fig. 4) might correspond to $\mathrm{Y}_{2} \mathrm{O}_{3}$ inclusions dispersed in the matrix.

\subsection{Microhardness}

Tables 4 and 5 show the microhardness variation of microconstituents from the surface to the bulk of samples, for different holding times at 1550 and $1600{ }^{\circ} \mathrm{C}$. Microhardness values in $\alpha_{2}+\gamma$ were higher than those in the interdendritic $\gamma$ phase in every cast sample, and decreased from the surface to the inside of samples, following the decrease in the oxygen content with a similar curve profile. Microhardness values in the interdendritic $\gamma$ phase were similar in every sample (289-296 HV), and seemed to be independent of the holding time and superheating temperature.
Those samples heated up to $1600{ }^{\circ} \mathrm{C}$ showed slightly higher microhardness values in the lamellar constituent than those heated up to $1550{ }^{\circ} \mathrm{C}$ (average values of 293-309 $\mathrm{HV}$ for $1550{ }^{\circ} \mathrm{C}$ and $296-311 \mathrm{HV}$ for $1600{ }^{\circ} \mathrm{C}$ ). Average $\alpha_{2}+\gamma \mathrm{mi}-$ crohardness values were also affected by the holding time, for a given superheating temperature (Tables 4 and 5).

The "alpha-case" thickness was a little below $100 \mu \mathrm{m}$ in samples heated up to $1550{ }^{\circ} \mathrm{C}$ and a little higher than $100 \mu \mathrm{m}$ in samples heated up to $1600{ }^{\circ} \mathrm{C}$ (Figs. 5 and 6). However, for each superheating temperature, the "alpha-case" thickness was not affected by the holding time (Figs. 5 and 6).

\subsection{Metal-crucible interface}

Figs. 7 and 8 show the microstructures at the metal-crucible wall interface for different superheating time/temperature pairs. For every sample, a continuous layer of inclusions with higher density than the cast alloy, that the EDS spectrum suggests as yttrium oxide (Fig. 9a), was present at the surface, as well as the lamellar microconstituent $\alpha_{2}+\gamma$ (Fig. 9b). At the interface, the $\gamma$ phase was not present due to the higher cooling rate in that region when compared with the bulk of the samples $[3,11]$.

Figs. 7, 8 and 10 reveal that the thickness of the yttrium oxide layer depended on both the superheating temperature and holding time. For $T=1550{ }^{\circ} \mathrm{C}$, the layer thickness varied from $15 \mu \mathrm{m}$ for $t_{\mathrm{h}}=60 \mathrm{~s}$ to $35 \mu \mathrm{m}$ for $t_{\mathrm{h}}=120 \mathrm{~s}$. For $T=1600{ }^{\circ} \mathrm{C}$, that value varied from $25 \mu \mathrm{m}$ for $t_{\mathrm{h}}=60 \mathrm{~s}$ to $65 \mu \mathrm{m}$ for $t_{\mathrm{h}}=120 \mathrm{~s}$.

Table 6 summarises the influence of superheating temperature and holding time on some characteristics of the cast Ti48Al samples.

\section{Discussion}

The average chemical composition of every sample was very close to the desired $\mathrm{Ti}-48 \mathrm{Al}$ standard alloy, as presented in Tables 2 and 3, suggesting that $1550{ }^{\circ} \mathrm{C}$ superheating temperature and $60 \mathrm{~s}$ holding time were enough to produce the alloy from commercially pure titanium and aluminium. However, the presence of residual elements like $\mathrm{Y}$ and $\mathrm{O}$ in solution (Tables 2 and 3) reveals that some sort of interaction occurred between the $\mathrm{Y}_{2} \mathrm{O}_{3}$ layer of the melting crucible and the

Table 4

Microhardness variation from the bulk to the surface of cast $\mathrm{Ti}-48 \mathrm{Al}$ samples, for different holding times at $1550{ }^{\circ} \mathrm{C}$

\begin{tabular}{|c|c|c|c|c|c|c|c|c|c|c|c|c|}
\hline \multirow[t]{3}{*}{ Holding time (s) } & \multicolumn{12}{|c|}{ Microhardness (HV) } \\
\hline & & \multicolumn{11}{|c|}{ Depth from surface $(\mu \mathrm{m})$} \\
\hline & & 50 & 100 & 150 & 200 & 250 & 300 & 500 & 1000 & 2000 & 3000 & Average on bulk \\
\hline \multirow[t]{2}{*}{60} & $\alpha_{2}+\gamma$ & 303 & 296 & 296 & 296 & 293 & 293 & 296 & 291 & 293 & 296 & 293 \\
\hline & $\gamma$ & - & 289 & 291 & 291 & 291 & 286 & 286 & 289 & 289 & 289 & 289 \\
\hline \multirow[t]{2}{*}{90} & $\alpha_{2}+\gamma$ & 306 & 396 & 296 & 296 & 296 & 296 & 291 & 293 & 296 & 299 & 299 \\
\hline & $\gamma$ & - & 293 & 296 & 286 & 293 & 293 & 289 & 289 & 293 & 289 & 289 \\
\hline \multirow[t]{2}{*}{120} & $\alpha_{2}+\gamma$ & 313 & 309 & 306 & 309 & 309 & 311 & 306 & 309 & 309 & 309 & 309 \\
\hline & $\gamma$ & - & 289 & 283 & 286 & 293 & 289 & 289 & 286 & 289 & 289 & 289 \\
\hline
\end{tabular}


Table 5

Microhardness variation from the bulk to the surface of cast $\mathrm{Ti}-48 \mathrm{Al}$ samples, for different holding times at $1600{ }^{\circ} \mathrm{C}$

Holding time (s) Microhardness (HV)

\begin{tabular}{|c|c|c|c|c|c|c|c|c|c|c|c|c|}
\hline & & \multicolumn{11}{|c|}{ Depth from surface $(\mu \mathrm{m})$} \\
\hline & & 50 & 100 & 150 & 200 & 250 & 300 & 500 & 1000 & 2000 & 3000 & Average on bulk \\
\hline \multirow[t]{2}{*}{60} & $\alpha_{2}+\gamma$ & 311 & 299 & 296 & 293 & 293 & 296 & 293 & 293 & 296 & 293 & 296 \\
\hline & $\gamma$ & - & 291 & 291 & 291 & 293 & 291 & 293 & 289 & 291 & 291 & 291 \\
\hline \multirow[t]{2}{*}{90} & $\alpha_{2}+\gamma$ & 311 & 303 & 301 & 296 & 296 & 301 & 291 & 301 & 296 & 299 & 301 \\
\hline & $\gamma$ & - & 296 & 291 & 296 & 296 & 289 & 301 & 296 & 296 & 296 & 293 \\
\hline \multirow[t]{2}{*}{120} & $\alpha_{2}+\gamma$ & 319 & 313 & 309 & 306 & 311 & 311 & 309 & 306 & 309 & 311 & 311 \\
\hline & $\gamma$ & - & 289 & 286 & 296 & 301 & 301 & 289 & 296 & 296 & 289 & 296 \\
\hline
\end{tabular}

cast alloy. According to its free energy of formation, $\mathrm{Y}_{2} \mathrm{O}_{3}$ is thermodynamically much more stable than titanium and aluminium oxides, thus no reaction of the crucible inner layer with the cast alloy should be expected. Thus, the most probable cause is the dissolution of the $\mathrm{Y}_{2} \mathrm{O}_{3}$ layer by the metal, which confirms the results of other researchers [12-14]. Moreover, the presence of small particles of $\mathrm{Y}_{2} \mathrm{O}_{3}$ both

a)

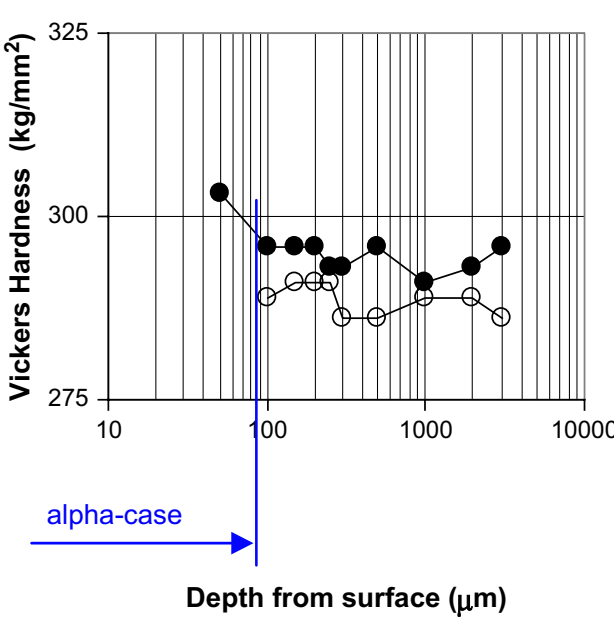

c)

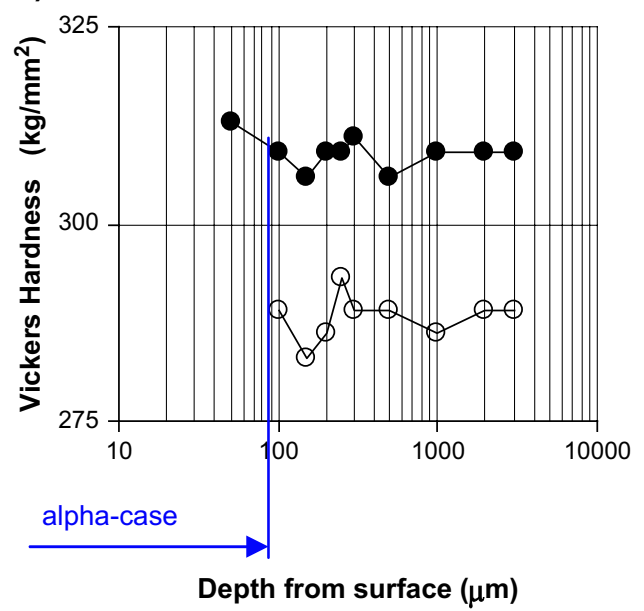

dispersed in the matrix (Fig. 1) and as a continuous film at the samples surface (Figs. 7 and 8), suggests that besides dissolution, an erosion phenomenon of the inner $\mathrm{Y}_{2} \mathrm{O}_{3}$ layer of the melting crucible might have occurred, in agreement with other researchers [12].

These findings suggest that some aspects of the experimental technique used in this work need to be improved, namely

b)

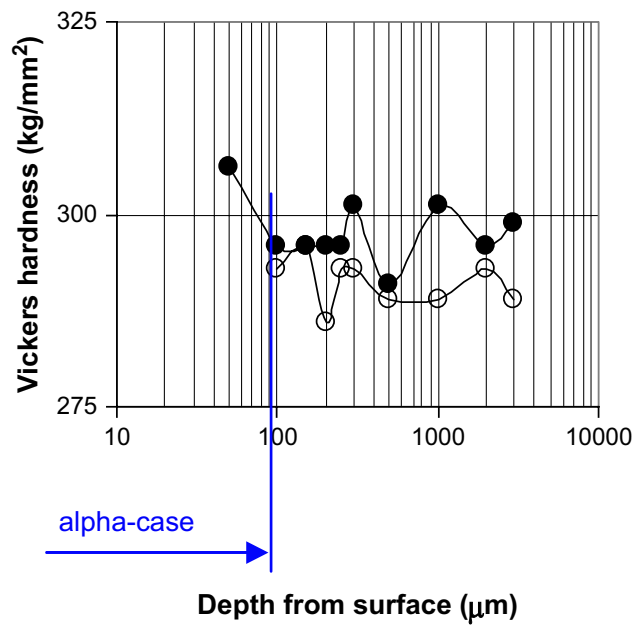

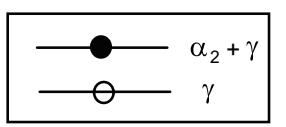

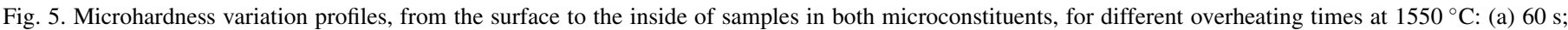
(b) $90 \mathrm{~s}$; (c) $120 \mathrm{~s}$. 
a)

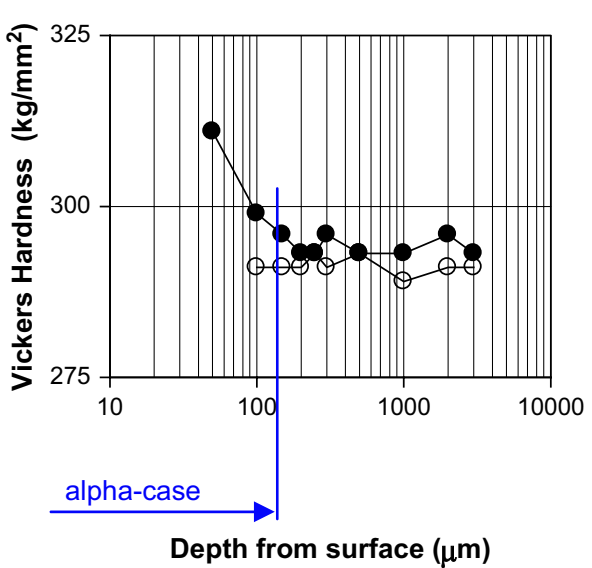

c)

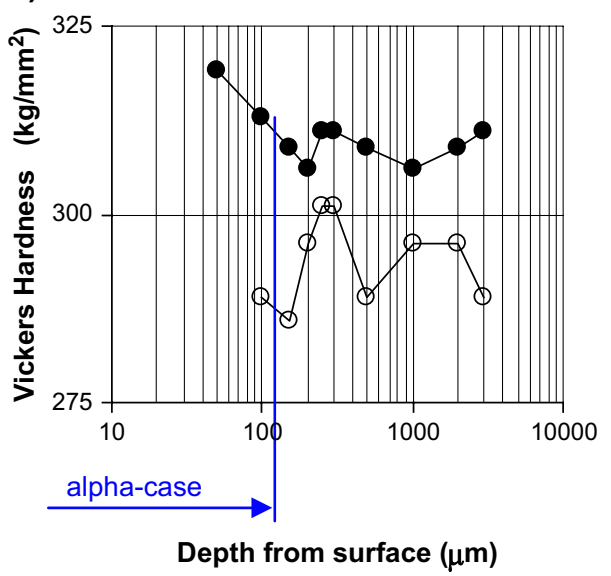

b)

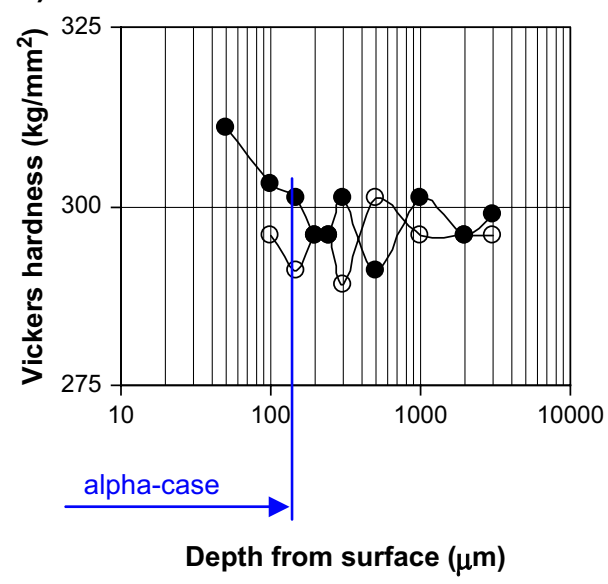

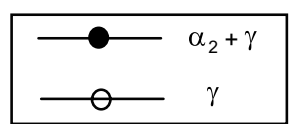

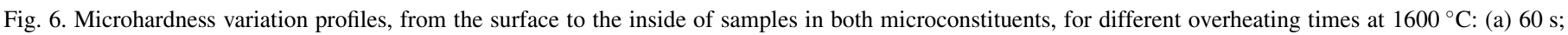
(b) $90 \mathrm{~s}$; (c) $120 \mathrm{~s}$.

the technique used to produce the $\mathrm{Y}_{2} \mathrm{O}_{3}$ layer. In fact, that layer was applied by painting followed by a drying operation, and no sintering was performed; thus porosity was high and some erosion might have occurred. Thus, independently from its chemical behaviour against the cast alloy, the porosity of the yttria layer should be decreased and the mechanical resistance should be improved, either by sintering (although it is a better solution than the one used in this work, some loose $\mathrm{Y}_{2} \mathrm{O}_{3}$ particles dispersed in the matrix can't be excluded [12]), or by using a different deposition techniques, like plasma spraying, for example. Nevertheless, the absence of $\mathrm{Zr}$ in the cast alloy revealed the effective barrier capability of the $\mathrm{Y}_{2} \mathrm{O}_{3}$ layer avoiding contact between the crucible base material $\left(\mathrm{ZrO}_{2}\right)$ and the molten metal, due to its good wettability facing TiAl, which is also referred by other researchers for full $\mathrm{Y}_{2} \mathrm{O}_{3}$ melting crucibles [12].

In Fig. 11, the average $\mathrm{Y}$ content of the cast samples and the concentration at $25 \mu \mathrm{m}$ from the surface are plotted against the holding time for both superheating temperatures. It is clearly seen that the average $\mathrm{Y}$ content of the cast samples is directly proportional both to the holding time and to the superheating temperature, suggesting that the extent of the
$\mathrm{Y}_{2} \mathrm{O}_{3}$ coating dissolution was a function of those parameters. When metal reached the liquid state and its fluidity became high enough, it could easily penetrate the interstices between the $\mathrm{Y}_{2} \mathrm{O}_{3}$ grains, thus increasing the erosion effect and the grain dissolution rate. Although the stirring effect of induction heating was not very high due to the high frequency of the melting furnace $(1.3 \mathrm{MHz})$, it helped to distribute those $\mathrm{Y}_{2} \mathrm{O}_{3}$ particles detached from the coating in the liquid metal, which dissolved them, and the dissolution products ( $\mathrm{Y}$ and O) went into solution with the alloy. Thus, a uniform composition was easily reached, whose value depended on the dissolution extent, which in turn depended on the melt temperature and the holding time. However, when the heating stopped and cooling started, the metal fluidity decreased very quickly, the erosion mechanism became much slower, the distribution of yttria particles in the alloy stopped, and they were retained at the samples' surface as a layer (Figs. 7 and 8 ). The thickness of the layer depended on the superheating temperature and the holding time, as they affect the metal fluidity and the metal-refractory contact time, respectively, and, as a consequence, the amount of particles detached from the crucible wall at the moment when the heating stopped. 

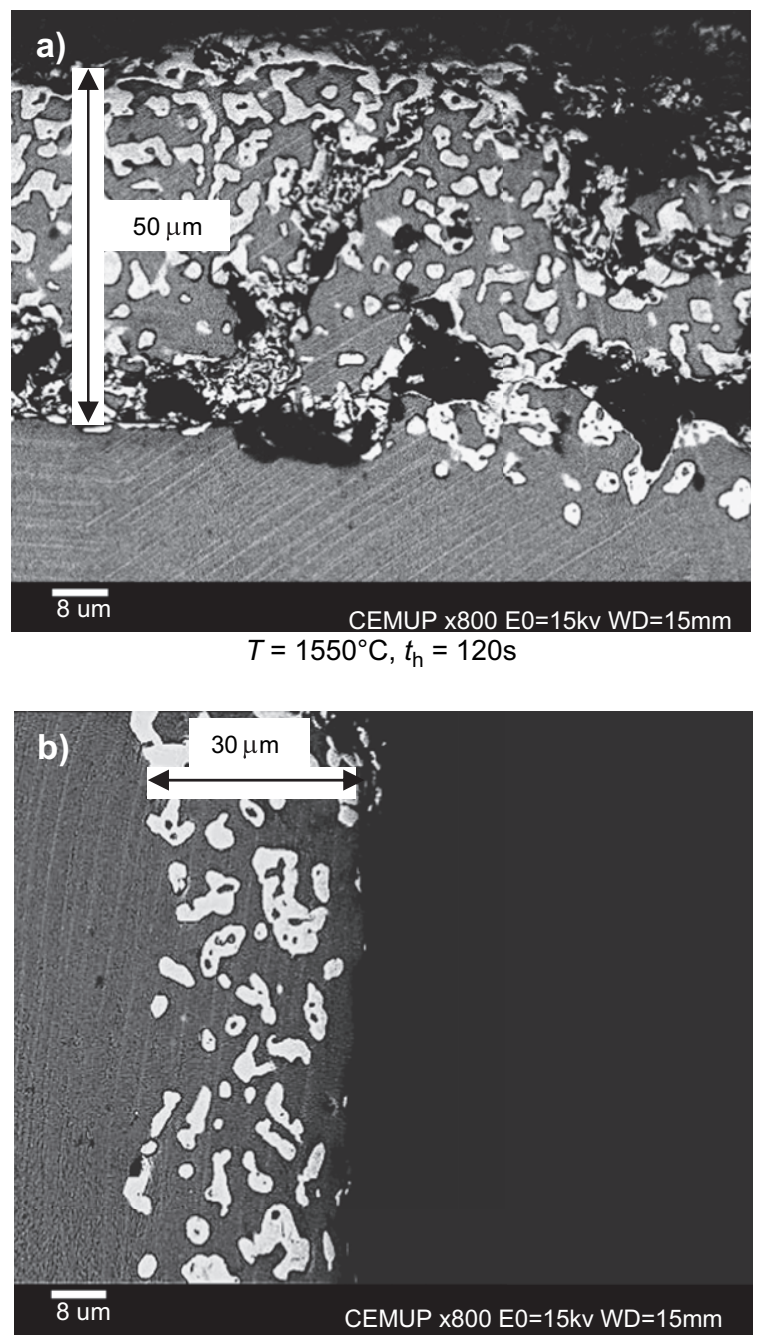

$T=1550^{\circ} \mathrm{C}, t_{\mathrm{h}}=90 \mathrm{~s}$

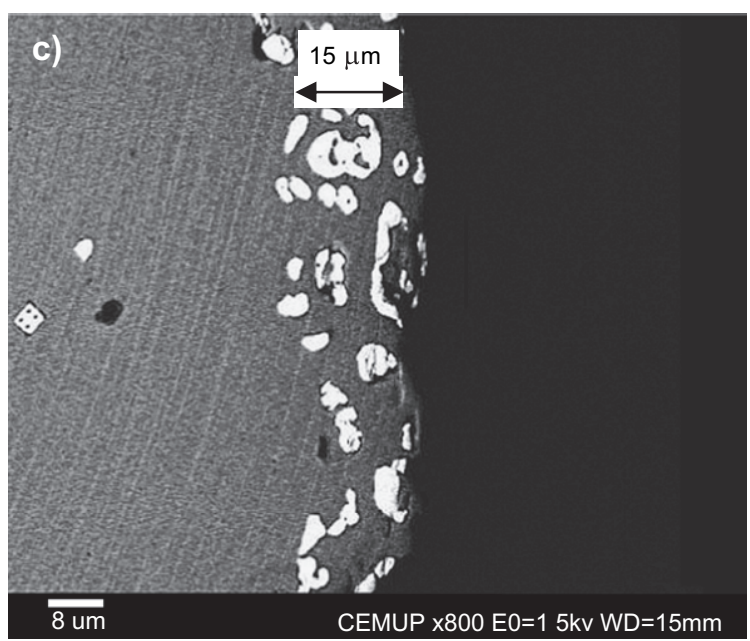

$T=1550^{\circ} \mathrm{C}, t_{\mathrm{h}}=60 \mathrm{~s}$

Fig. 7. Yttria layer at the $\mathrm{Ti}-48 \mathrm{Al}$ samples surface for different holding times at $1550{ }^{\circ} \mathrm{C}$

In order to confirm this mechanism, one sample was allowed to solidify after reaching $1500{ }^{\circ} \mathrm{C}$, just when the first liquid metal could be seen. In that sample, neither $\mathrm{Y}_{2} \mathrm{O}_{3}$ particles nor $\mathrm{Y}$ and $\mathrm{O}$ contaminations were found at the sample

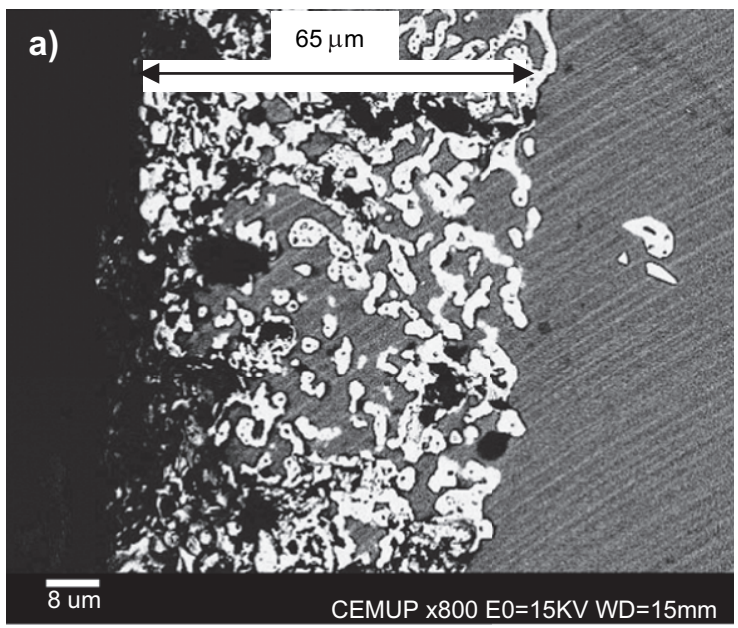

$T=1600^{\circ} \mathrm{C}, t_{\mathrm{h}}=120 \mathrm{~s}$

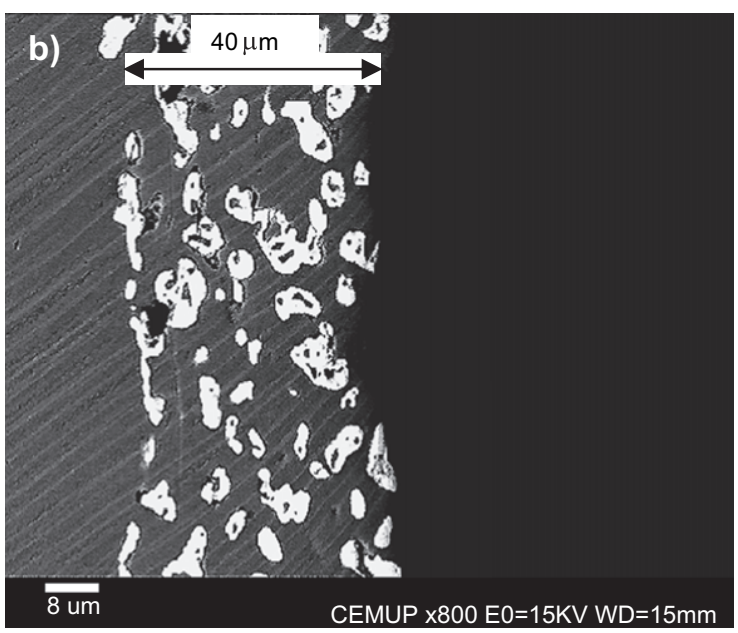

$T=1600^{\circ} \mathrm{C}, t_{\mathrm{h}}=90 \mathrm{~s}$

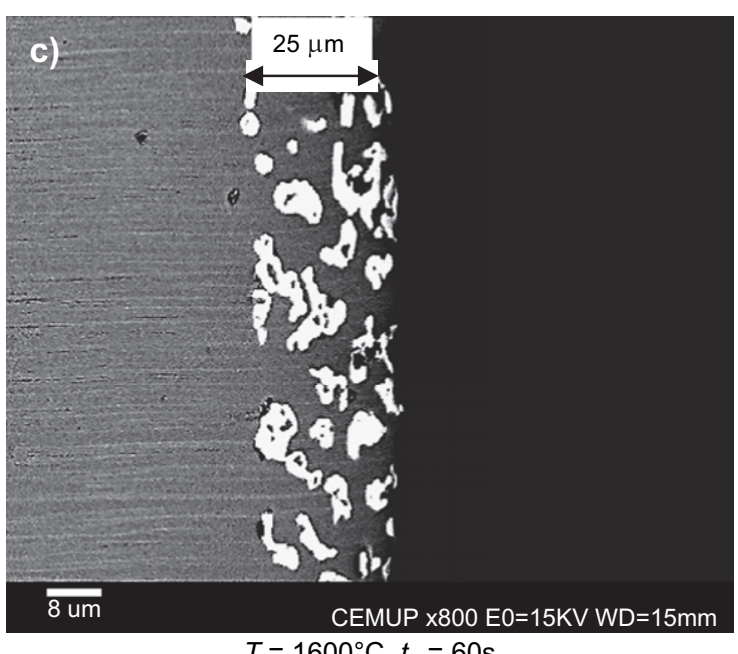

Fig. 8. Yttria layer at the cast Ti-48Al samples surface for different holding times at $1600^{\circ} \mathrm{C}$.

surface or in the bulk, suggesting that erosion and diffusion mechanisms started only after the metal reached the liquid state, and no reaction occurred in the solid/mushy state, which agrees with the free energy of formation of $\mathrm{Y}_{2} \mathrm{O}_{3}$. 
a)

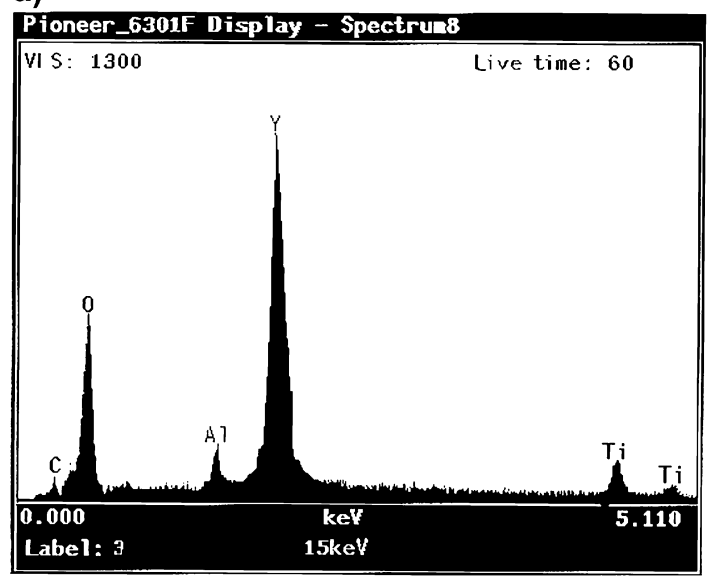

$\mathrm{Y}_{\mathrm{x}} \mathrm{O}_{\mathrm{y}}$ b)

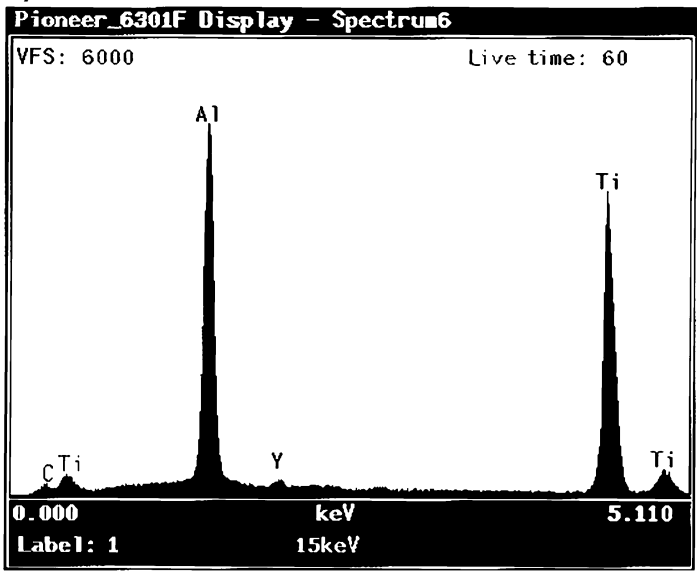

$\alpha_{2}+\gamma$

Fig. 9. EDS spectrums of microconstituents present at a Ti-48Al sample surface, overheated at $1600{ }^{\circ} \mathrm{C}$ for $120 \mathrm{~s}$.

The presence of dispersed $\mathrm{Y}_{2} \mathrm{O}_{3}$ particles suggests that in some cases they were not completely dissolved by the molten metal. Another possible explanation could be the re-precipitation during cooling/solidification, due to the reduction in the solubility of $\mathrm{Y}$ and $\mathrm{O}$, although this explanation seems to be not so consistent. In fact, as the $\mathrm{O}$ and $\mathrm{Y}$ concentrations decrease gradually from the surface towards the bulk (Fig. 4 and Tables 2 and 3), the volume fraction of $\mathrm{Y}_{2} \mathrm{O}_{3}$ particles should follow the same tendency, but it doesn't. On the other hand, those samples with higher $\mathrm{O}$ and $\mathrm{Y}$ contents should reveal a higher volume fraction of particles, which is not the case, as it is quite similar in every cast sample.

As the temperature decreased, dissolution and diffusion rates of $\mathrm{Y}$ and $\mathrm{O}$ became much slower, mainly after the start of solidification, leading to concentration gradients from the surface to the inside of samples (Tables 2 and 3 and Fig. 4). As the cooling conditions (metal and crucible temperatures, crucible material) were the same for each superheating temperature, they led to similar dissolution and diffusion rates, and as a consequence, to similar $\mathrm{Y}$ and $\mathrm{O}$ concentration gradients from the surface to the inside of the cast samples, independently of the holding time. Fig. 11 reveals that the

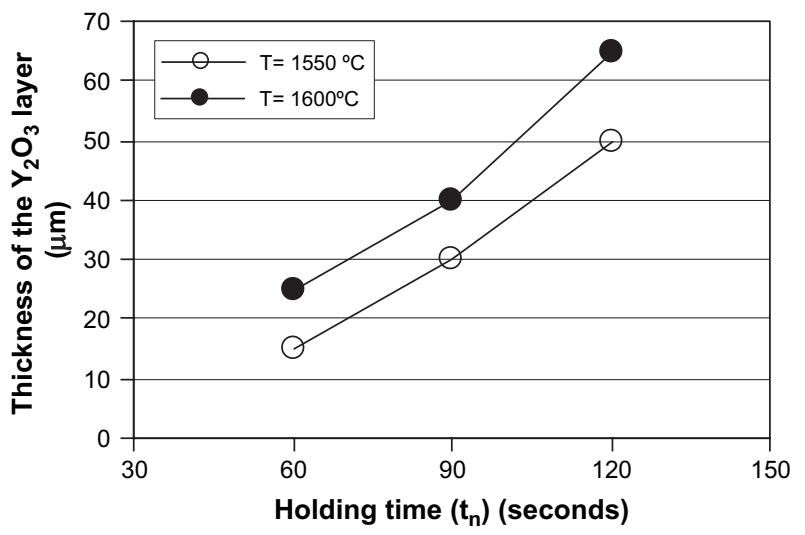

Fig. 10. Thickness of the yttrium oxide layer for different holding times at 1550 and $1600{ }^{\circ} \mathrm{C}$. increase of the $\mathrm{Y}$ content at the surface after cooling started was almost constant for each superheating temperature, and did not depend on the holding time - around 0.07 at $\%$ for $T=1550{ }^{\circ} \mathrm{C}$ (Fig. 11a) and around 0.1 at $\%$ for $T=1600{ }^{\circ} \mathrm{C}$ (Fig. 11b). For graphical representation purpose, the average $\mathrm{Y}$ content for $60 \mathrm{~s}$ holding time was considered to be 0.1 at $\%$, although the real value was lower than that (Tables 2 and 3). Thus, the balance to the $\mathrm{Y}$ concentration at $25 \mu \mathrm{m}$ from the sample surface was in fact higher than the one plotted, for both superheating temperatures.

The dissolution of the $\mathrm{Y}_{2} \mathrm{O}_{3}$ coating was confirmed by the overall oxygen content of the cast alloys, which also depended on the superheating parameters as they led to different dissolution extents. In fact, the oxygen content of the cast samples $-0.21-0.26 \mathrm{wt} \%$ for $T=1550{ }^{\circ} \mathrm{C}$ and $0.24-0.31 \mathrm{wt} \%$ for $T=1600{ }^{\circ} \mathrm{C}$ (Fig. 3b) - was higher than it should be. According to the melting stock composition, the maximum oxygen content should be around $0.16 \mathrm{wt} \%$ (see Table 1). Furthermore, melting was performed in a dry argon atmosphere, to exclude the possibility of oxygen pick-up. Thus, the oxygen enrichment of the cast alloy due to the melting operation was between 500 and $1500 \mathrm{ppm}$, depending on both the superheating temperature and holding time (Table 6). These values are slightly higher than those reported for cast TiAl melted in full $\mathrm{Y}_{2} \mathrm{O}_{3}$ sintered crucibles [12], but are much lower than those referred by other researchers for similar crucibles (although no information is presented about their production technique [14-16]) as well as for TiAl obtained in other current ceramic crucibles, like $\mathrm{CaO}[1,3], \mathrm{ZrO}_{2}[3,14]$, and $\mathrm{Al}_{2} \mathrm{O}_{3}$ [12] based ones.

The oxygen content of the cast alloys is the main reason for microhardness variation as it dissolves interstitially in the matrix. For this reason, the microhardness of the $\alpha_{2}+\gamma$ constituent and the oxygen concentration profiles are quite similar, decreasing inwards from the samples' surfaces reaching constant values after similar distances from the surface (Figs. 4-6). This is related to the fact that oxygen dissolves preferentially in the lamellar constituent being almost constant in the $\gamma$ 
Table 6

Influence of overheating parameters in some characteristics of cast $\mathrm{Ti}-48 \mathrm{Al}$ samples

\begin{tabular}{|c|c|c|c|c|c|c|c|c|c|c|}
\hline \multirow{3}{*}{$\begin{array}{l}\text { Superheating } \\
\text { temperature }\left({ }^{\circ} \mathrm{C}\right)\end{array}$} & \multirow{3}{*}{$\begin{array}{l}\text { Holding } \\
\text { time (s) }\end{array}$} & \multirow{3}{*}{$\begin{array}{l}\mathrm{Y}_{2} \mathrm{O}_{3} \\
\text { layer }(\mu \mathrm{m})\end{array}$} & \multirow{3}{*}{$\begin{array}{l}\text { Alpha-case } \\
\text { extension }(\mu \mathrm{m})\end{array}$} & \multicolumn{7}{|c|}{ Inside the sample } \\
\hline & & & & \multicolumn{3}{|c|}{ Composition (at\%) } & \multicolumn{2}{|c|}{ Dissolved oxygen (wt\%) } & \multicolumn{2}{|c|}{ Microhardness (HV) } \\
\hline & & & & $\mathrm{Ti}$ & $\mathrm{Al}$ & Y & Final & Incorporated & $\alpha_{2}+\gamma$ & $\gamma$ \\
\hline \multirow[t]{3}{*}{1550} & 60 & 15 & $\approx 90$ & 52.0 & 47.9 & $<0.1$ & 0.21 & 0.05 & 293 & 289 \\
\hline & 90 & 30 & $\approx 90$ & 51.7 & 48.2 & 0.11 & 0.24 & 0.08 & 299 & 289 \\
\hline & 120 & 50 & $\approx 90$ & 53.1 & 46.8 & 0.14 & 0.26 & 0.10 & 309 & 299 \\
\hline \multirow[t]{3}{*}{1600} & 60 & 25 & $\approx 105$ & 52.3 & 47.7 & $<0.1$ & 0.24 & 0.08 & 296 & 291 \\
\hline & 90 & 40 & $\approx 105$ & 51.8 & 48.1 & 0.12 & 0.28 & 0.12 & 301 & 293 \\
\hline & 120 & 65 & $\approx 105$ & 52.2 & 47.6 & 0.16 & 0.31 & 0.15 & 311 & 296 \\
\hline
\end{tabular}

phase, where its solubility limit is around $230 \mathrm{ppm}$ [17]. As a consequence, if no other residual elements are present in solution, the microhardness variation profile in $\alpha_{2}+\gamma$ represents, in fact, the oxygen variation profile in the cast alloy $[3,4,13,14]$. Due to such a strict relationship, the microhardness depends significantly on the superheating temperature and holding time, because as these parameters increase, the more extensive is the crucible material dissolution, with a consequent increase in the alloy oxygen content. Although there was a small microhardness increase at the surface, the maximum value $319 \mathrm{HV}$ - was significantly lower than those reported by other researchers for as-cast $\mathrm{Ti}-48 \mathrm{Al}[2,5]$ and agrees with suggested microhardness values for this kind of alloy [18].

For the same reason, the oxygen diffusion depth also corresponds to the "alpha-case" thickness, which can be confirmed by comparing Fig. 4 with Figs. 5 and 6 . The "alpha-case" thickness was a little below $100 \mu \mathrm{m}$ in samples heated up to $1550{ }^{\circ} \mathrm{C}$ and a little higher than $100 \mu \mathrm{m}$ in samples heated up to $1600{ }^{\circ} \mathrm{C}$ (Figs. 5 and 6), as a consequence of different cooling rates that led to different diffusion depths of oxygen (Fig. 4). Looking at Fig. 4, these values correspond to those distances from the surface where the oxygen concentrations become similar to the average values inside the samples. However, for each superheating temperature, the "alpha-case" thickness was not affected by the holding time (Figs. 5 and
6), because oxygen concentration gradients from the surface to the inside of samples started to develop only when cooling starts, as explained before. Although there is an effective harder layer of around $100 \mu \mathrm{m}$ thickness at the surface, the maximum microhardness value in that region $(319 \mathrm{HV})$ is only $8.8 \%$ higher than the average value in the bulk $(293 \mathrm{HV})$, which means that the hardness increase at the surface is in fact very small. Moreover, the maximum value of $319 \mathrm{HV}$ is still low enough to avoid chemical milling.

In this work, it was not possible to evaluate the influence of $Y$ content on the microhardness. In $\alpha_{2}+\gamma$, it was not possible to characterize the individual effect of $\mathrm{Y}$ and $\mathrm{O}$, as both elements showed a gradient in concentration from the surface to the inside of samples. In the $\gamma$ interdendritic phase, where the $\mathrm{O}$ content remained constant and the $\mathrm{Y}$ concentration decreased from the surface to a depth between 25 and $50 \mu \mathrm{m}$, it was not possible to measure microhardness due to the very small volume fraction of $\gamma$ phase in that area.

\section{Conclusions}

- For the processing conditions used in this work, it is possible to obtain cast $\mathrm{Ti}-48 \mathrm{Al}$ from melting stocks made of commercially pure titanium and aluminium, using $1550{ }^{\circ} \mathrm{C}$ superheating temperature for $60 \mathrm{~s}$. a)

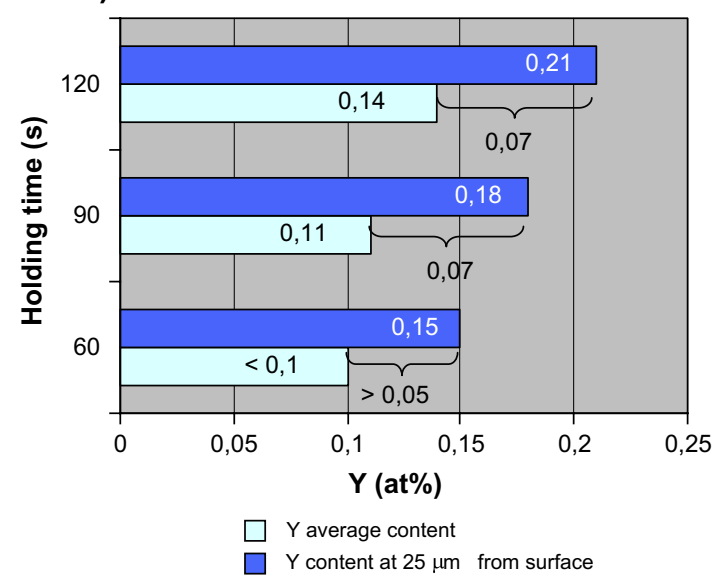

b)

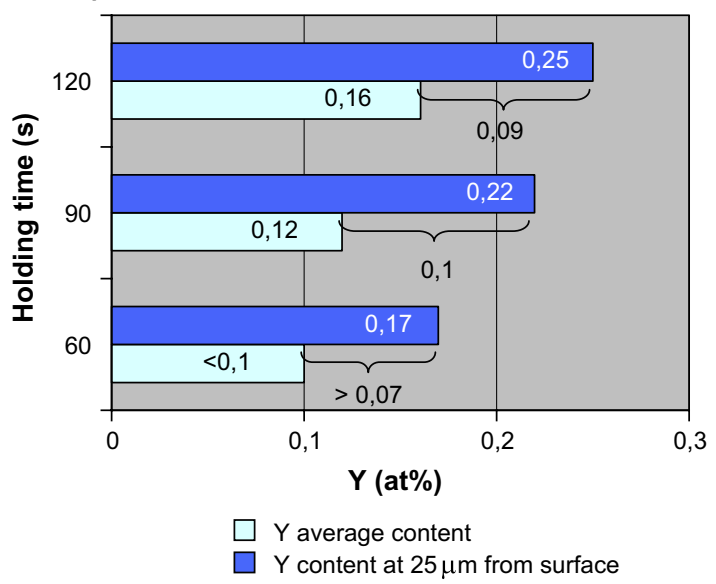

Fig. 11. Y content variation from the bulk to the surface of Ti-48Al samples, for different holding times at (a) $1550{ }^{\circ} \mathrm{C}$ and (b) $1600{ }^{\circ} \mathrm{C}$. 
- $\mathrm{Y}_{2} \mathrm{O}_{3}$ was found to be a suitable material to be used as face-coat of melting crucibles for induction melting of TiAl alloys, although erosion phenomena and a slight dissolution by the molten alloys can still occur.

- Superheating temperature and holding time are important factors in the interaction between melting crucibles with an $\mathrm{Y}_{2} \mathrm{O}_{3}$ face-coat and molten TiAl and directly influence the concentration of residual elements and microhardness.

- The extent of the "alpha-case" depends on the superheating temperature, but it is independent of the holding time.

\section{Acknowledgements}

Authors want to acknowledge Portuguese Foundation for Science and Technology for financially supporting this work, and the Department of Mechanical Engineering of University of Minho for the provision of research facilities.

\section{References}

[1] Liu K, Ma YC, Gao M, Rao GB, Li YY, Wei K, et al. Single step centrifugal casting TiAl automotive valves. Intermetallics 2005;11: 925-8.

[2] Sung Si-Young, Kim Young-Jig. Economic net-shape forming of TiAl alloys for automotive parts. Intermetallics 2006;14:1163-7.

[3] Barbosa J. Elaboração de Aluminetos de Titânio por Fusão de Indução em Cadinho Cerâmico e Vazamento em Moldação Cerâmica, PhD thesis, University of Minho, Portugal; 2001.

[4] Barbosa J, Ribeiro C Silva, Caetano Monteiro A. Evaluation of $\mathrm{Y}_{2} \mathrm{O}_{3}$ as front layer of ceramic crucibles for vacuum induction melting of TiAl based alloys, Proceedings of the EPD Congress 2005 (2005 TMS annual meeting). San Francisco, USA: TMS; 2005. p. 573-84.
[5] Jovanovic MT, Dimicic B, Bobic I, Zec S, Maksimovic V. Microstructure and mechanical properties of precision cast TiAl turbocharger wheel. Journal of Materials Processing Technology 2005;167:14-21.

[6] Mi J, Harding RA, Wickins M, Campbell J. Entrained oxide films in TiAl castings. Intermetallics 2003;11:377-85.

[7] Roy TK, Balasubramaniam R, Ghosh A. Determination of oxygen and nitrogen diffusivities in titanium aluminides by subscale microhardness profiling. Scripta Materialia 1996;34(9):1425-30.

[8] Barbosa J, Ribeiro C Silva, Caetano Monteiro A. Processo para Obtenção de Peças em $\gamma$ TiAl por Fundição, Portuguese Patent PT103018; 2006.

[9] Barbosa J, Ribeiro C Silva, Caetano Monteiro A. Process for obtaining $\gamma$ TiAl pieces by casting, Patent Pending WO2005/025778 A1; 2006.

[10] Ramanujan RV, Maziasz PJ, Liu CT. The thermal stability of the microstructure of $\gamma$-based titanium aluminides. Acta Materialia 1996; 44(7):2611-42.

[11] Mitao S, Tsuyama S, Minakawa K. Effects of microstructure on the mechanical properties and fracture of $\gamma$-based titanium aluminides. Materials Science and Engineering 1991;A143:51-62.

[12] Kuang JP, Harding RA, Campbell J. A study of refractories as crucible and mould materials for melting and casting $\gamma$-TiAl alloys. International Journal of Cast Metals Research 2001;13:227-92.

[13] Reetz T. Keramische Werkstoffe fur Aluminium und Titanschmelzen. Giesserei 1996;83(16):53-6.

[14] Saha RL, Nandy TK, Misra RDK, Jacob KT. On the evaluation of stability of rare earth oxides as face coats for investment casting of titanium. Metallurgical Transactions 1990;21B:559-66.

[15] Schadlich-Stubenrauch J, Dieckhues GW, Sahm PR. Investment casting technology for titanium and Ti-aluminide near net shape parts. In: Twenty seventh dedicated conference on new and alternative materials for the transportation industries, Aachen, Germany; 1994.

[16] Richerson D, Schuyler D. Ceramic composition and crucibles and molds formed therefrom. U.S. Patent 4040845; 1997. p. 3.

[17] Menand A, Huguet A, Nérac-Partaix A. Interstitial solubility in $\gamma$ and $\alpha_{2}$ phases of TiAl-based alloys. Acta Materialia 1996;44(12):4729-37.

[18] Materials properties handbook - titanium alloys. Ohio: ASM; 1994. p. 1011-34. [Section VI - Advanced materials - titanium aluminides]. 